\title{
Contrasting effects of urban habitat complexity on metabolic functional diversity and composition of litter and soil bacterial communities
}

\author{
Alessandro Ossola ${ }^{* 1}$, Cristina Aponte ${ }^{1}$, Amy K. Hahs ${ }^{2,3}$, Stephen J. Livesley ${ }^{1}$ \\ ${ }^{1}$ School of Ecosystem and Forest Sciences, The University of Melbourne, 500 Yarra \\ Boulevard, 3121, Richmond, VIC, Australia. \\ 2 Australian Research Centre for Urban Ecology, Royal Botanic Gardens Victoria, Birdwood \\ Ave, South Yarra, Victoria 3141, Australia \\ ${ }^{3}$ School of BioSciences, The University of Melbourne, Parkville, Victoria 3010, Australia
}

*Corresponding author: alessandro.ossola@ unimelb.edu.au, tel: +61 390355511 


\section{Abstract}

Functional diversity and composition of soil bacterial communities affect important soil biogeochemical processes. In natural and semi-natural ecosystems, variations in habitat complexity have been shown to significantly impact both litter and soil bacterial communities. However, this remains largely untested in urban ecosystems, where human management can lead to habitat complexity combinations unobserved in rural ecosystems. We established 10 research plots in low-complexity park, high-complexity park, and highcomplexity remnant habitat types $(n=30)$ in Melbourne, Australia. The use of organic carbon substrates by soil and litter bacteria was measured using EcoPlates to investigate the effects of habitat complexity upon metabolic functional diversity and functional composition of bacterial communities of i) soil and ii) one-year old litter. Direct and indirect effects of habitat complexity, microclimate and decomposition status upon litter microbial functional diversity and composition were also modelled using path analysis. Soil bacterial communities had significantly higher functional diversity compared to litter bacterial communities, but no significant effect of habitat complexity was apparent. The functional composition of soil bacterial communities was not affected by habitat complexity. In contrast, the functional composition of litter bacterial communities in high complexity parks and remnants was significantly different from that in low-complexity parks. The functional composition of litter bacterial communities, but not their diversity, was directly affected by habitat complexity and microclimate as well as their indirect effects upon the decomposition status of litter. Human management of urban habitat complexity can alter the functional composition of litter and soil bacterial communities without affecting their functional diversity. While this can have significant impacts on bacteria-regulated processes and ecosystem services, it also suggests that urban bacterial communities might be able to adjust to further environmental and climatic changes affecting urban ecosystems. 


\section{Keywords}

Evenness, habitat structure, habitat management, time since land-use change, microclimate, understory

\section{Introduction}

In urban ecosystems, human management is the major determinant of habitat complexity. Management practices create and sustain urban habitat complexity over time, frequently generating novel structural combinations not observed in natural or semi-natural ecosystems (Byrne 2007; Ossola et al. 2016). Practices such as planting, litter removal or grass mowing, can alter vegetation, litter and soil habitat components, thereby increasing or decreasing overall habitat complexity. A pause or lack of management and maintenance can also lead to natural plant re-colonisation and secondary succession with a consequent increase in habitat complexity, as typically observed in vacant lots (Koehler 2000; Gough and Elliott 2012).

Habitat complexity has a significant influence on the functional diversity and composition of microbial communities (i.e. bacteria and fungi) in natural and semi-natural rural ecosystems (Cantrell et al. 2014; González et al. 2014). In these ecosystems, vegetation thinning, understory removal, afforestation or natural regrowth can all impact functional diversity and compositional structure of microbial communities (Berthrong et al. 2009; Lin et al. 2011; Wu et al. 2011; Hortal et al. 2013). Changes in the forest floor complexity, for instance following litter addition or removal, can also significantly affect soil and litter microbes (Li et al. 2004; Sayer 2006; Cantrell et al. 2014). Ultimately, habitat complexity greatly influences the forest microclimate (Savva et al. 2010; Korb et al. 2014; Ossola et al. 2016), indirectly regulating litter decomposition and microbial succession (Fioretto et al. 2000).

The functional diversity and composition of soil and litter microbial communities drive important biogeochemical processes such as organic matter decomposition (McGuire and 
Treseder 2010; Hättenschwiler et al. 2011; Allison et al. 2013), soil respiration and nitrogen mineralisation (Balser and Firestone 2005; Strickland et al. 2009). Artificially constructed soil microbial communities have shown that higher species richness of both bacteria and fungi can enhance litter decomposition and soil respiration (Setälä and McLean 2004; Wohl et al. 2004; Bell et al. 2005; Matulich and Martiny 2015). However, naturally occurring soil microbial communities are composed of thousands of species, most of them functionally equivalent (i.e. redundant) (Nannipieri et al. 2003; Setälä and McLean 2004; Fierer et al. 2007). The functional diversity of microbial communities, rather than their taxonomic diversity, has thus been suggested as a more accurate predictor of biogeochemical processes, particularly litter decomposition (Hättenschwiler et al. 2011). In general, microbial diversity and composition on soil surface litter evolves over time based on several factors, such as substrate quality (i.e. C:N) and proportion of recalcitrant compounds (Rinkes et al. 2014). Within a few weeks of litterfall, the easily-decomposable compounds will have been exploited by the early microbial colonisers, after which litter microbial community stabilises and changes more slowly (Marschner et al. 2011; Voriskova and Baldrian 2013). Eventually, the overall diversity and composition of the microbial community on a certain litter type at a particular point in time will primarily depend on the decomposition status of litter (DeAngelis et al. 2013; Smith et al. 2015).

Some recent studies found urban habitat complexity to affect numerous biogeochemical and hydrological processes in urban ecosystems (Byrne et al. 2008; Ossola et al. 2015a; Livesley et al. 2016). Habitat complexity was also a major determinant of detritivore comminution and microbial decomposition processes in urban ecosystems (Ossola et al. 2016). However, its effects on the metabolic functional structure of soil and litter bacterial communities remain untested to date.

Therefore, this study was set out to address the following research questions: 
i) Are metabolic functional diversity and composition of bacterial communities living on decomposing litter and the soil beneath affected by urban habitat complexity as determined by human management?

ii) How do habitat complexity, microclimate and decomposition status moderate metabolic functional diversity and functional composition of litter microbial communities?

In particular, since habitat complexity can influence the structure of bacterial communities in natural ecosystems, we hypothesised that the metabolic functional diversity of bacterial communities would be enhanced by higher urban habitat complexity. We also hypothesised that the functional composition of litter and soil communities would be different between high- and low-complexity habitats.

\section{Materials and Methods}

\section{Experimental design}

This study was conducted in south-east Melbourne, Australia, as part of a larger project aimed to investigate the effects of urban habitat complexity, defined as the amount of physical biotic and abiotic components (e.g. vegetation, mulch, gravel, etc) of a habitat (Byrne 2007), on soil biodiversity and biogeochemical processes (Ossola et al. 2015a, 2015b, 2016). Ten research plots $(20 \times 30 \mathrm{~m})$, for each of three habitat complexity types, i) highcomplexity remnants (HCR), ii) high-complexity parks (HCP) and iii) low-complexity parks (LCP), were established over a single soil type (Podosols). Two HCR plots were randomly selected in each of five Eucalyptus heathy woodland remnants. Thus, HCR plots never underwent land-use change in the last century and they are currently managed for conservation purposes by local councils (e.g. weeding, native species planting). Two HCP and two LCP plots were selected in the out-of-play area of each of five metropolitan golf 
courses. Based on historical records, these five golf courses were established on former agroecosystems between 43 and 100 years ago. Since then, HCP plots were not actively managed, allowing vegetation re-colonisation and litter accumulation. In contrast, LCP plots were consistently managed through monthly mowing $(\sim 5 \mathrm{~cm}$ from soil surface) but without irrigation or fertilisation. We assumed LCP plots to be also representative of public urban parks having similar management practices and habitat complexity.

In each plot, 23 habitat variables were measured to characterise the complexity of vegetation, litter and soil. Methodological details have been reported elsewhere (Ossola et al. 2015b, 2016). Briefly, tree height and diameter at breast height $(130 \mathrm{~cm})$ were measured for all the stems (>8 cm diameter) in each plot to calculate tree basal area and above-ground biomass. Understory volume was measured using a point-intercept method (Threlfall et al. 2016) and reported as percent volume occupied by vegetation in five horizontal strata $(0-0.2 \mathrm{~m}, 0.2-0.5$ $\mathrm{m}, 0.5-1 \mathrm{~m}, 1-2 \mathrm{~m}$ and total $0-2 \mathrm{~m}$ ). The complexity of the litter layer was characterised by measuring percent cover of bare soil, litter and grass, as well as the average litter mass on the ground. Soil $(0-10 \mathrm{~cm})$ in each plot was characterised in term of physical structure (bulk density, texture, aggregate distribution, porosity) and chemical properties (C, N, C:N, SOM). A litter bag experiment was also performed to measure organic matter microbial decomposition using litter bags ( 10 x $10 \mathrm{~cm}, 0.2 \mathrm{~mm}$ mesh size) containing $\sim 3 \mathrm{~g}$ oven-dried leaves $\left(70^{\circ} \mathrm{C}, 48 \mathrm{hrs}\right)$ collected from a single Eucalyptus globulus tree (Ossola et al. 2016). Litter bag mesh size prevented any fauna from accessing the litter inside, and no sign of litter comminution was noticeable upon bag collection. Eucalyptus globulus was selected to avoid home-field advantage effects since this species was not recorded in any plot (Gholz et al. 2000). Three sets of litter bags for each of three time replicates (70, 170 and 365 days) were installed at random locations on the soil surface of each research plot during the austral autumn (April 2013). Based on the litter mass remaining in the bags at different times, 
decomposition rates $(\mathrm{k} 2 \mathrm{~L})$ were calculated using negative exponential models as detailed in Ossola et al. (2016). Thus, k2L values are used in this study as an indicator of the decomposition status of the same standard Eucalyptus litter after 365 days of incubation in the field. During the decomposition experiment, litter temperature was measured every three hours with iButtons (model DS1922, Maxim Integrated, San Jose, CA, USA) and averaged to calculate diurnal (06:00 - 18:00), nocturnal (18:00 - 06:00) and daily temperatures in each plot.

In the present study, bacterial analyses were performed on the litter remaining in the litter bags from Ossola et al. (2016) collected at 365 days ( 30 plots $\mathrm{x} 3$ replicates $=90$ samples $)$ to avoid the fluctuations in bacterial populations typical of the early decomposition stages (Marschner et al. 2011; Voriskova and Baldrian 2013). Soil under each set of litter bags was also sampled during the collection of bags at the end of the decomposition experiment to allow the extraction of soil bacteria. Specifically, a soil core $(0-5 \mathrm{~cm}$ depth, $2 \mathrm{~cm}$ diameter $)$ was taken from under each of the three sets of litter bags in each research plot (30 plots x 3 replicates $=90$ samples). Soil was homogenised and transferred to sterile vials, which were refrigerated $\left(4^{\circ} \mathrm{C}\right)$ until laboratory analyses were performed within a week from sampling.

\section{Laboratory analyses}

A detachment protocol adapted from Buesing and Gessner (2002) was used to detach bacterial cells from the Eucalyptus litter remaining in the litter bags, as well as from the original Eucalyptus litter used to prepare litter bags (3 samples). Litter and sterile $0.85 \%$ $\mathrm{NaCl}(50 \mathrm{ml})$ were mixed in sterile air-tight vials. Vials were placed in a temperaturecontrolled $\left(30^{\circ} \mathrm{C}\right)$ ultrasonic bath for 15 minutes and then in a shaker for 15 minutes. Similarly, soil (5 g) was extracted with sterile $0.85 \% \mathrm{NaCl}(50 \mathrm{ml})$ shaking for 15 minutes. 
Vials containing the bacterial suspensions from litter and soil were allowed to rest for $1 \mathrm{~h}$ for particles to set before plating.

EcoPlates $^{\mathrm{TM}}$ (Biolog, Inc., Hayward, CA, USA) were used to characterise metabolic functional diversity and functional composition of bacterial communities of two substrates, i) Eucalyptus leaf litter remaining in the last set of litter bags (365 days) and ii) soil sampled under each set of litter bags from the three habitat complexity types. EcoPlates use a community-level physiological profiling approach based on multiple carbon sources to characterise the metabolic function of bacterial communities (Weber and Legge 2010). EcoPlates do not provide indication of the taxonomic diversity of bacterial communities. However, the functional diversity measured through this technique has been often linked to microbial genetic and taxonomic diversity (Leflaive et al., 2008, Miki et al., 2013). Thus, they represent a standard methodology to compare bacterial metabolic functions of large sets of samples from a variety of substrates. Each EcoPlate consisted of three replicate wells containing 31 carbon sources and a blank (see Table 3 for details). When bacteria use a particular carbon substrate in the well, a tetrazolium dye is reduced to formazan which can be measured photometrically. Due to their inability to use the tetrazolium dye, fungi do not contribute to the colour development of EcoPlates (Preston-Mafham et al. 2002). Each well in an EcoPlate was inoculated with $150 \mu \mathrm{L}$ of the same undiluted bacterial suspension and aerobically incubated in the dark at $25^{\circ} \mathrm{C}$ (Weber and Legge 2010). Absorbance at $590 \mathrm{~nm}$ of each well was measured using a Multiskan ${ }^{\circledR}$ Spectrum spectrophotometer (v.1.2, Thermo Scientific, Waltham, MA, USA) after 48, 72 and $96 \mathrm{~h}$ of incubation to check colour development. Only $96 \mathrm{~h}$ readings have been used for statistical analyses. Prior to EcoPlate analysis, a random subset of bacterial suspensions was tested to ensure that the minimum cell density $\left(10^{5}\right.$ cells $\left./ \mu \mathrm{L}\right)$ for the EcoPlate to develop colour was achieved (Weber and Legge 
2010). EcoPlates $(n=3)$ inoculated with the bacterial extraction from the oven-dried litter used to prepare litter bags did not develop dyeing profiles detectable by the microplate reader.

\section{Statistical analyses}

The absorbance values of each well in a plate was corrected by the respective blank readings and divided by the average well colour development (AWCD) for that incubation time (Weber et al. 2007). Shannon diversity index (H) and evenness (E) were used to assess the metabolic functional diversity of bacterial communities in leaf litter and soil (Zak et al. 1994; Chen et al. 2015). $\mathrm{H}$ and $\mathrm{E}$ were calculated respectively as:

$$
\left.H=-\sum p_{i} \ln \left(p_{i}\right) \quad \text { (Equation } 1\right)
$$

and

$$
E=\frac{H}{H_{\max }}=\frac{H}{\ln (S)} \quad \text { (Equation 2) }
$$

where $\mathrm{p}_{\mathrm{i}}$ is the ratio between the absorbance of a particular well and the sum of the absorbance of all wells, and $\mathrm{S}$ is the number of wells with absorbance greater than 0.25 (Zak et al. 1994; Weber and Legge 2010). The effects of habitat type, substrate (soil, litter) and time since land-use change (from agro-ecosystem to park) upon $\mathrm{H}$ and $\mathrm{E}$ were tested using linear mixed models fitted with a restricted maximum likelihood (REML) estimation using 'site' as random-effect variable at a significance level of 0.05 . The use of linear mixed-effect models allowed to account for the unbalanced number of samples due to the loss of some litter bags in LCP ( $\mathrm{n}=3$ ) during the decomposition experiment (Ossola et al. 2016).

Non-metric multidimensional scaling (NMDS) on a Bray-Curtis dissimilarity matrix was used to assess differences in the functional composition of bacterial communities in soil and 
on the decomposed leaf litter (365 days) in the three habitat types. The same dissimilarity matrix was used for a permutational analysis of variance (PERMANOVA) based on 99,999 permutations, followed by pairwise comparisons. NMDS and PERMANOVA analyses were performed on i) corrected absorbance readings ( $96 \mathrm{~h}$ ) of the single 31 carbon sources, and ii) the absorbance $(96 \mathrm{~h})$ for the carbon functional guilds (i.e. amine, amino acids, carbohydrates, carboxylic acids, phenolic compounds, polymers) where the 31 carbon sources have been classified and weighted accordingly to Leflaive et al. (2005) (see Table 3). Box-Cox transformations were performed on absorbance data prior to analyses to improve normality. Environmental variables were added to the NMDS ordinations by using the "envfit" function of the vegan R library (Oksanen et al. 2014).

Partial least squares path modelling (PLS-PM) was used to model direct and indirect effects of habitat complexity, microclimate and litter decomposition status upon metabolic functional diversity and functional composition of litter bacterial communities. PLS-PM is a path analysis recently used to explore direct and indirect relationships among observed and latent variables within multivariate ecological datasets (Sanchez 2013; Barberán et al. 2014; Kendrick et al. 2015). We composed each of the three path models with two latent variables, 'habitat and microclimate' (exogenous) and 'decomposition status' (endogenous), as well as a further endogenous latent variable among 'functional composition (C sources)', 'functional composition (Guilds)' and 'metabolic functional diversity'. In particular, this path allowed the analysis of direct effects of habitat and microclimate upon bacterial communities, but also their indirect effects through the biophysical regulation of decomposition processes. Observed variables for the 'habitat and microclimate' latent variable (i.e. total understory volume, basal area, litter mass, nocturnal and daily temperatures) were selected using a stepwise selection based on the variance inflation factor to exclude multicollinearity and also being significant predictors of Eucalyptus litter 
microbial decomposition rates (Ossola et al. 2016). K2L was selected as manifest variable for the 'decomposition status' latent variable. The latent variables 'functional composition $(C$ sources)' and 'functional composition (Guilds)' contained the absorbance values for the litter $\mathrm{C}$ sources and guilds as observed variables, respectively. Path analysis was not conducted on soil bacterial communities since below-ground decomposition rates were not measured in this study.

PERMANOVA analyses were performed using Primer 6 and PERMANOVA+ (Anderson et al. 2008). All the other statistical analyses were performed using R 3.1.0 (R Core Team, 2012) with the additional packages lme4 (Bates et al. 2014), vegan (Oksanen et al. 2014), plspm (Sanchez et al. 2015) and nlme (Pinheiro et al. 2015). Average values are reported with the standard error of the mean, unless otherwise stated.

\section{Results}

Detailed results for all the habitat complexity, decomposition and microclimatic variables measured in each habitat type have been reported elsewhere (Ossola et al. 2015b, 2016). Briefly, HCP and HCR habitats had similar overall habitat complexity, significantly different from that of LCP habitats (Fig. 1A). In particular, the total volume $(0-2 \mathrm{~m})$ occupied by understory vegetation in HCR and HCP was $59.0 \pm 2.9 \%$ and $58.8 \pm 6.8 \%$, respectively. This volume decreased to $18.8 \pm 2.8 \%$ in LCP. Tree basal area in LCP $\left(46.4 \pm 6.4 \mathrm{~m}^{2} / \mathrm{ha}\right)$ was about twice that in high complexity habitats $\left(\mathrm{HCR}=24.6 \pm 4.5 \mathrm{~m}^{2} / \mathrm{ha} ; \mathrm{HCP}=28.8 \pm 5.3\right.$ $\mathrm{m}^{2} / \mathrm{ha}$ ). Litter mass on the ground in HCR and LCP was $\sim 76 \%$ and $33 \%$ of that recorded in $\mathrm{HCP}\left(1.1 \pm 0.1 \mathrm{~kg} / \mathrm{m}^{2}\right)$. Based on their physicochemical properties, soils were similar across all plots, and as such no distinction among habitat complexity types was apparent in the NMDS ordination based on soil variables (Fig. 1B). The Eucalyptus litter mass remaining after 365 days was significantly lower in $\mathrm{HCR}(42.3 \pm 1.0 \%)$ and $\mathrm{HCP}(44.1 \pm 2.1 \%)$ as 
compared to $\operatorname{LCP}(50.9 \pm 1.2 \%)$. Consequently, average microbial decomposition rates $(\mathrm{k} 2 \mathrm{~L})$ were significantly higher in HCR (0.0033) and HCP (0.0030) as compared to LCP (0.0023), indicating more advanced decomposition status of the Eucalyptus litter in more complex habitats after 365 days in the field. While nocturnal average temperatures were similar across the habitat types $\left(\sim 14^{\circ} \mathrm{C}\right)$, average daily temperature was $\sim 1^{\circ} \mathrm{C}$ lower in $\mathrm{HCP}\left(15.9 \pm 0.2^{\circ} \mathrm{C}\right)$ compared to $\mathrm{HCR}$ and $\mathrm{HCP}\left(16.7 \pm 0.1\right.$ and $16.8 \pm 0.2^{\circ} \mathrm{C}$, respectively).

Metabolic functional diversity $(\mathrm{H})$ and evenness (E) were not affected by habitat complexity type (Table 1). However, metabolic functional diversity and evenness were significantly higher in soil as compared to litter (Fig. 2). A significant interaction was observed between substrate (soil, litter) and time since land-use change (Table 1, Fig. 2). NMDS ordinations based on both single $\mathrm{C}$ sources and functional guilds revealed a significantly different functional composition of litter bacterial communities as compared to those living in the soil (Pseudo- $\mathrm{F}_{5,173}=7.21, \mathrm{p}<0.001$ and pseudo- $\mathrm{F}_{5,173}=7.44, \mathrm{p}<0.001$ for single $\mathrm{C}$ sources and functional guilds, respectively; Fig. 3). Pairwise comparisons post-PERMANOVA revealed that the functional composition of soil bacterial communities was similar in the three habitat types, except for the soil bacterial communities in HCR and LCP characterised through the single C sources (Table 2). The functional composition of litter bacterial communities in LCP was significantly different from that of HCP and HCR based on both their utilisation of single $\mathrm{C}$ sources and the functional guilds (Table 2). The functional composition of litter bacterial communities in HCP and HCR was positively related to polymers, while those living on the litter in LCP to amino acids (Table 3). The functional composition of soil bacterial communities was also related to phenolic acids, amine, carboxylic acids and carbohydrates, though no relationship among habitat complexity types was apparent (Fig. 3).

The PLS-PM analysis showed that habitat complexity, and to a lesser extent microclimate, had a significant effect on microbial decomposition processes (Fig. 4). The functional 
composition of litter bacterial communities measured through the $\mathrm{C}$ sources utilisation was directly affected by 'habitat and microclimate' and indirectly by 'decomposition status', with the latter having larger effects (Fig. 4A). Five carbohydrates had positive loadings $(>0.4)$ with 'functional composition (C sources)' latent variable, while three amino acids and one amine had negative loadings (Table 3). Litter 'functional composition (Guilds)' latent variable was also directly affected by 'habitat and microclimate', and indirectly through their control on the 'decomposition status' of litter (Fig. 4B). Loadings for the habitat complexity variables were generally higher than those for the microclimate variables for all the path models generated (Fig. 4). Litter bacterial metabolic functional diversity and evenness was not affected by either 'habitat and microclimate' or 'decomposition status' (Fig. 4C).

\section{Discussion}

\section{Bacterial community structure in simple and complex urban habitats}

Contrary to expectations, metabolic functional diversity and evenness of both litter and soil bacterial communities were not enhanced by higher urban habitat complexity. Similarly, Yao et al. (2006) reported no significant variation in the metabolic functional diversity of soil bacterial communities after the conversion of native pine forests to turfgrass-dominated parklands (i.e. golf courses) in Raleigh, NC. Interestingly, a recent study in a tropical forest in Puerto Rico showed that manipulations of the complexity of canopy and litter layers aimed to simulate the effect of hurricanes had significant effects on the taxonomic diversity of litter microbial communities, though no metabolic functional response was measured (Cantrell et al. 2014). The lack of significant results in our study suggests that soil and litter bacterial communities might well adjust to changes in urban habitat complexity, as those driven by human management of urban ecosystems (e.g. mowing, litter removal, understory removal, 
human trampling, etc). These practices might determine a lower disturbance intensity and have milder impacts on bacterial communities compared to other practices more typical of natural and semi-natural ecosystems (e.g. logging, tillage, burning, afforestation), which have been demonstrated to greatly affect microbial functional diversity (e.g. Giai and Boerner 2007; Chen et al. 2015).

Time since land-use change provided a temporal indication of when habitat complexity of HCP and LCP started to diverge due to different management practices. Overall, metabolic functional diversity and evenness of both litter and soil bacterial communities were not affected by time since land-use change. Moreover, urban habitats that underwent land-use change (43-100 years ago) and remnant native habitats had the same metabolic functional diversity of litter and soil microbial communities. This again conforms to findings from Yao et al. (2006) that reported soil metabolic functional diversity not to be affected by the time (195 years) since the conversion of pine forests to turfgrass systems. Soil bacterial communities had significantly higher metabolic functional diversity and evenness compared to litter microbial communities. However, this is not surprising since microbes able to colonise litter and persist during litter decomposition generally represent a subset of those living in the soil (Bray et al. 2012). Also, many biogeochemical processes are performed by soil microbes rather than those on litter, potentially determining the higher soil metabolic functional diversity observed.

Our hypothesis, that habitat complexity would affect the functional composition of soil bacterial communities, was also not confirmed. This contradicts numerous observations from natural and agro-ecosystems where habitat complexity had significant effects upon both functional and taxonomic composition of soil microbial communities (Li et al. 2004; Yao et 
al., 2006; Wu et al. 2011; Cantrell et al. 2014; Smith et al. 2015). In a similar urban study, Zhao et al. (2013) also found that the metabolic functional composition of soil bacterial communities was significantly different across multiple land uses (i.e. urban secondary forest, agriculture, streetscape, park) displaying different habitat complexities in Beijing, China. In our study, soil physico-chemical properties between high- and low-complexity habitat types were generally similar (Fig. 1B) (Ossola et al. 2015a, b). Soil properties also had a relatively small influence on superficial organic matter decomposition compared to vegetation, litter and microclimate variables (Ossola et al. 2016). While the habitat types investigated in this study significantly differed in their structural complexity, they were also similar in terms of tree species identity, being dominated by various species of eucalypts (Ossola et al., 2015b). This might have determined inputs of organic matter of comparable quality (e.g. C:N, oils, tannins, etc) into the soil through the litter layer and the rhizosphere across the habitat complexity types. Because soil properties and vegetation composition are major factors affecting soil microbes (Girvan et al. 2003; Fierer and Jackson 2006; Prescott and Grayston 2013), it is therefore reasonable that no differences in the functional composition of soil bacterial communities were found.

In contrast, the functional composition of litter bacterial communities developing on the same standard Eucalyptus substrate after 365 days of decomposition was significantly affected by habitat complexity, as originally hypothesised. Litter bacterial communities were functionally similar in HCP and HCR, and significantly different from those in LCP. The same pattern of variation was also observed for Eucalyptus leaf litter decomposition in the same research plots (Ossola et al. 2016). Litter microbial decomposition proceeded at the same rate in HCP and HCR. Therefore, it is reasonable that the litter bacterial communities in HCP and HCR changed similarly during litter decomposition determining the same final metabolic functional composition. Overall, comparing HCP to HCR habitat types, no land-use legacy 
effect of the former agricultural past of HCP was apparent on litter bacterial metabolic functional diversity, functional composition and litter microbial decomposition. Evidence from numerous other abandoned post-agricultural systems suggests the presence of longlasting legacies in soil and vegetation properties, as well as microbial communities (e.g. Brudvig et al. 2013; Fichtner et al. 2014). However, these effects were not apparent in the urban ecosystems investigated, possibly due to the relatively long time since land-use change or due to the soil type investigated. This suggests that perhaps appropriate long-term management practices that aim to increase the complexity of urban habitats towards that of native remnant ecosystems can promote the restoration of soil microbial communities, soil processes and the overall health of urban soil (Millward et al. 2011; Ossola et al., 2016).

The functional composition of bacterial communities, analysed using both single $\mathrm{C}$ sources and functional guilds, was overall significantly different between soil and litter (Fig.3, Table 1). Recent studies investigating microbial communities in natural forests found the taxonomic composition of soil and litter communities to be also significantly different (DeAngelis et al. 2013; Smith et al. 2015). Kim et al. (2014) argued that the difference in microbial community taxonomic composition between litter and the soil underneath might be as large as the difference between litter communities in temperate and tropical climates. In our study, we did not investigate the functional composition of bacteria on the litter already fallen in our plots, but we allowed enough time (i.e. 365 days) for the standard Eucalyptus leaf litter contained in the litter bags to be colonised from the surrounding habitat. In this way, we avoided confounding effects due to multiple litter chemistries and/or decomposition stages typical of the standing litter (Cantrell et al. 2014; Smith et al. 2015). Future research should investigate how multi-species litter mixtures at different decomposition stages affect litter microbial functional diversity and ecological processes. This is particularly relevant in urban ecosystems, where plant diversity, and therefore litter input, is significantly affected by large 
native and exotic species pools of varying quality and proportions (Aronson et al. 2014; Threlfall et al. 2016).

\section{Effects of habitat complexity on the metabolic functional diversity and composition of}

\section{litter bacteria}

The functional composition of the bacterial community on the one-year old eucalypt litter was related to i) direct effects of 'habitat and microclimate' and ii) indirect effects of 'habitat and microclimate' as mediated by their control on litter 'decomposition status' (Fig. 4). However, indirect effects were more important in explaining the final bacterial functional composition, as quantified by both $\mathrm{C}$ sources and functional guilds. The overall microbial community composition varies during litter decomposition based on the concurrent changes in litter chemistry and this might determine changes to the functional composition of bacterial communities (Ribeiro et al. 2002; Ngao et al. 2009; Šnajdr et al. 2011). Nonetheless, litter chemistry appears to exert a more important control during early decomposition, whereas microbial community composition drives decomposition at later stages (Bray et al. 2012). For this reason, the final community composition has been used in various studies looking at the relationship between microbial community structure and decomposition processes (Bray et al. 2012; Matulich and Martiny 2015). It is therefore plausible that in our study the indirect effects of 'habitat and microclimate', in regulating the litter 'decomposition status', might have been more important in structuring the litter bacterial functional composition, as measured by $\mathrm{C}$ sources and guilds, compared to their direct effects.

Interestingly, metabolic functional diversity and evenness of litter bacterial communities were not predicted by 'habitat and microclimate' characteristics or indirectly by their control on litter 'decomposition status'. Previous studies have similarly observed no consistent 
relationship between microbial taxonomic or functional diversity and decomposition processes (Degens 1998; Nannipieri et al. 2003). Artificial manipulations of bacterial and fungal communities have demonstrated soil processes can be enhanced by increased species richness (Setälä and McLean 2004; Wohl et al. 2004; Matulich and Martiny 2015). While this relationship is apparent in species-poor communities (n. species <20), it tends to disappear as species richness approaches levels more typical of natural communities (i.e. hundreds or thousands species), suggesting an increase in functional redundancy (Bell et al., 2005). Similarly in our study, the functional diversity of litter bacteria might have been sufficiently high to determine high functional redundancy and therefore no relationship with decomposition processes. Microbial taxonomic and functional composition, rather than its diversity per se, has been suggested to be related to decomposition processes in numerous studies (Balser and Firestone 2005; McGuire and Treseder 2010; Allison et al. 2013; Matulich and Martiny 2015). It is therefore plausible that also in this study decomposition status had a significant effect upon the metabolic functional composition of bacterial communities but not on their functional diversity.

\section{Conclusions}

The variation of urban habitat complexity mediated by human management can significantly alter the functional composition of litter bacterial communities, particularly through the indirect regulation of decomposition processes. However, soil and litter bacteria functional diversity seems not to be affected by the disturbance generated through common urban habitat management practices. This suggests that urban bacterial communities could be more functionally resistant than previously thought and potentially able to adapt to further environmental and climatic changes affecting urban ecosystems. The simplification of urban habitats should nonetheless be avoided, particularly where urban managers aim to preserve 
functional litter and soil microbial communities, as well as the processes supported by these organisms. This is of paramount importance considering that urban soil processes can have cascading effects on numerous other ecological processes and important ecosystem services for our cities and towns.

\section{Acknowledgements}

This project was funded by the Australian Research Council (ARC LP 110100686), the Australian Research Centre for Urban Ecology (ARCUE) at the Royal Botanic Gardens Victoria, and the Australian Golf Course Superintendents' Association (AGCSA). Authors declare no conflict of interest. AO, CA, AKH and SJL conceived of the study design. AO performed research. AO and CA analysed data. AO wrote the paper with scientific and editorial review by CA, AKH and SJL. AO was supported by MIFRS and MIRS scholarships, the David Lachlan Hay Memorial Fund and an US National Academy of Sciences, Engineering and Medicine NRC Associateship. Belinda Lees, Carolyn Selway and Vince Kalangi provided valuable laboratory assistance. Authors are also grateful to the AGSCA Members and the Municipalities of Kingston, Frankston and Greater Dandenong for their collaboration. The editor and reviewers of an earlier version of this manuscript are also acknowledged for their constructive comments.

\section{References}

Allison SD, Lu Y, Weihe C, Goulden ML, Martiny AC, Treseder KK, Martiny JBH (2013) Microbial abundance and composition influence litter decomposition response to environmental change. Ecology 94:714-725. 
Aronson MFJ, La Sorte FA, Nilon CH, Katti M, Goddard MA, Lepczyk CA, Warren PS, Williams NSG, Cilliers S, Clarkson B, Dobbs C, Dolan R, Hedblom M, Klotz S, Louwe Kooijmans J, Kühn I, MacGregor-Fors I, McDonnell M, Mörtberg U, Pyšek P, Siebert S, Sushinsky J, Werner P, Winter M (2014) A global analysis of the impacts of urbanization on bird and plant diversity reveals key anthropogenic drivers. Proc $\mathrm{R}$ Soc Lond B 281:20133330

Anderson MJ, Gorley RN, Clarke KR (2008) PERMANOVA+ for PRIMER: Guide to Software and Statistical Methods. Plymouth, UK: PRIMER-E.

Balser TC, Firestone MK (2005) Linking microbial community composition and soil processes in a California annual grassland and mixed-conifer forest. Biogeochemistry 73:395-415.

Barberán A, Ramirez KS, Leff JW, Bradford MA, Wall DH, Fierer N (2014) Why are some microbes more ubiquitous than others? Predicting the habitat breadth of soil bacteria. Ecol Lett 17:794-802.

Bates D, Maechler M, Bolker B, Walker S (2014) lme4: Linear mixed-effects models using Eigen and S4. R package version 1.1-7.

Bell T, Newman JA, Silverman BW, Turner SL, Lilley AK (2005) The contribution of species richness and composition to bacterial services. Nature 436:1157-1160.

Berthrong ST, Schadt CW, Piñeiro G, Jackson RB (2009) Afforestation alters the composition of functional genes in soil and biogeochemical processes in South American grasslands. Appl Environ Microbiol 75:6240-6248.

Bray SR, Kitajima K, Mack MC (2012) Temporal dynamics of microbial communities on decomposing leaf litter of 10 plant species in relation to decomposition rate. Soil Biol Biochem 49:30-37. 
Brudvig LA, Grman E, Habeck CW, Orrock JL, Ledvina JA (2013) Strong legacy of agricultural land use on soils and understory plant communities in longleaf pine woodlands. For Ecol Manage 310:944-955.

Buesing N, Gessner MO (2002) Comparison of detachment procedures for direct counts of bacteria associated with sediment particles, plant litter and epiphytic biofilms. Acquat Microb Ecol 27:29-36.

Byrne LB (2007) Habitat structure: a fundamental concept and framework for urban soil ecology. Urban Ecosyst 10:255-274.

Byrne LB, Bruns MA, Kim KC (2008) Ecosystem properties of urban land covers at the aboveground-belowground interface. Ecosystems 11:1065-1077.

Cantrell SA, Molina M, Jean Lodge D, Rivera-Figueroa FJ, Ortiz-Hernández ML, Marchetti AA, Cyterski MJ, Pérez-Jiménez JR (2014) Effects of a simulated hurricane disturbance on forest floor microbial communities. For Ecol Manage 332:22-31.

Chen X-L, Wang D, Chen X, Wang J, Diao J-J, Zhang J-Y, Guan Q-W (2015) Soil microbial functional diversity and biomass as affected by different thinning intensities in a Chinese fir plantation. Appl Soil Ecol 92:35-44.

DeAngelis KM, Chivian D, Fortney JL, Arkin AP, Simmons B, Hazen TC, Silver WL (2013) Changes in microbial dynamics during long-term decomposition in tropical forests. Soil Biol Biochem 66:60-68.

Degens BP (1998) Decreases in microbial functional diversity do not result in corresponding changes in decomposition under different moisture conditions. Soil Biol Biochem 30:1989-2000.

Fichtner A, von Oheimb G, Härdtle W, Wilken C, Gutknecht JLM (2014) Effects of anthropogenic disturbances on soil microbial communities in oak forests persist for more than 100 years. Soil Biol Biochem 70:79-87. 
Fierer N, Breitbart M, Nulton J, Salamon P, Lozupone C, Jones R, Robeson M, Edwards RA, Felts B, Rayhawk S, Knight R, Rohwer F, Jackson RB (2007) Metagenomic and small-subunit rRNA analyses reveal the genetic diversity of bacteria, Archaea, fungi, and viruses in soil. Appl Environ Microbiol 73:7059-7066.

Fierer N, Jackson RB (2006) The diversity and biogeography of soil bacterial communities. Proc Natl Acad Sci U.S.A. 103:626-631.

Fioretto A, Papa S, Curcio E, Sorrentino G, Fuggi A (2000) Enzyme dynamics on decomposing leaf litter of Cistus incanus and Myrtus communis in a Mediterranean ecosystem. Soil Biol Biochem 32:1847-1855.

Gholz HL, Wedin DA, Smitherman SM, Harmon ME, Parton WJ (2000) Long-term dynamics of pine and hardwood litter in contrasting environments: toward a global model of decomposition. Glob Chang Biol 6:751-765.

Giai C, Boerner REJ (2007) Effects of ecological restoration on microbial activity, microbial functional diversity, and soil organic matter in mixed-oak forests of southern Ohio, USA. Appl Soil Ecol 35:281-290.

Girvan MS, Bullimore J, Pretty JN, Osborn AM, Ball AS (2003) Soil type is the primary determinant of the composition of the total and active bacterial communities in arable soils. Appl Environ Microbiol 69:1800-1809.

González G, Lodge DJ, Richardson BA, Richardson MJ (2014) A canopy trimming experiment in Puerto Rico: The response of litter decomposition and nutrient release to canopy opening and debris deposition in a subtropical wet forest. For Ecol Manage $332: 32-46$

Gough C, Elliott HL (2012) Lawn soil carbon storage in abandoned residential properties: An examination of ecosystem structure and function following partial human-natural decoupling. J Environ Manage 98:155-162. 
Hättenschwiler S, Fromin N, Barantal S (2011) Functional diversity of terrestrial microbial decomposers and their substrates. C R Biol 334:393-402.

Hortal S, Bastida F, Armas C, Lozano YM, Moreno JL, García C, Pugnaire FI (2013) Soil microbial community under a nurse-plant species changes in composition, biomass and activity as the nurse grows. Soil Biol Biochem 64:139-146.

Kendrick JA, Ribbons RR, Classen AT, Ellison AM (2015) Changes in canopy structure and ant assemblages affect soil ecosystem variables as a foundation species declines. Ecosphere 6:art 77.

Kim M, Kim W-S, Tripathi B, Adams J (2014) Distinct bacterial communities dominate tropical and temperate zone leaf litter. Microb Ecol 67:837-848.

Koehler HH (2000) Natural regeneration and succession - results from a 13 years study with reference to mesofauna and vegetation, and implications for management. Landsc and Urban Plan 51:123-130.

Korb JE, Bombaci S, Siegel R (2014) The effect of sudden aspen decline on understory microclimate and vegetation in southwestern Colorado. Can J For Res 44:914-921.

Leflaive J, Céréghino R, Danger M, Lacroix G, Ten-Hage L (2005) Assessment of selforganizing maps to analyze sole-carbon source utilization profiles. J Microbiol Methods 62:89-102.

Leflaive J, Danger M, Lacroix G, Lyautey E, Oumarou C, Ten-Hage L (2008) Nutrient effects on the genetic and functional diversity of aquatic bacterial communities. FEMS Microbiol Ecol 66: 379-390.

Li Q, Lee Allen H, Wollum Ii AG (2004) Microbial biomass and bacterial functional diversity in forest soils: effects of organic matter removal, compaction, and vegetation control. Soil Biol Biochem 36:571-579. 
Lin WR, Chen WC, Wang PH (2011) Effects of forest thinning on diversity and function of macrofungi and soil microbes. Sydowia 63:67-77.

Livesley SJ, Ossola A, Threlfall C, Hahs AK, Williams NSG (2016) Soil carbon and carbon/nitrogen ratio change under tree canopy, tall grass and turf grass areas of urban green spaces. J Environ Qual 45:215-223.

Marschner P, Umar S, Baumann K (2011) The microbial community composition changes rapidly in the early stages of decomposition of wheat residue. Soil Biol Biochem $43: 445-451$.

Matulich KL, Martiny JBH (2015) Microbial composition alters the response of litter decomposition to environmental change. Ecology 96:154-163.

McGuire KL, Treseder KK (2010) Microbial communities and their relevance for ecosystem models: Decomposition as a case study. Soil Biol Biochem 42:529-535.

Miki T, Yokokawa T, Matsui K (2013) Biodiversity and multifunctionality in a microbial community: a novel theoretical approach to quantify functional redundancy. Proc R Soc Lond [Biol] 281: 20132498.

Millward AA, Kamal P, Briggs SE (2011) Naturalization as a strategy for improving soil physical characteristics in a forested urban park. Urban Ecosyst 14: 261-278.

Nannipieri P, Ascher J, Ceccherini MT, Landi L, Pietramellara G, Renella G (2003) Microbial diversity and soil functions. Eur J Soil Sci 54:655-670.

Ngao J, Bernhard-Reversat F, Loumeto J-J (2009) Changes in eucalypt litter quality during the first three months of field decomposition in a Congolese plantation. Appl Soil Ecol 42:191-199.

Oksanen J, Guillaume Blanchet F, Kindt R, Legendre P, Minchin P, O'Hara R, Simpson G, Solymos P, Stevens M, Wagner H (2014) vegan: Community Ecology Package. R package version 2.2-0. 
Ossola A, Hahs AK, Livesley SJ (2015a). Habitat complexity influences fine scale hydrological processes and the incidence of stormwater runoff in managed urban ecosystems. J Environ Manage 159:1-10.

Ossola A, Nash MA, Christie F, Hahs AK, Livesley SJ (2015b). Urban habitat complexity affects species richness but not environmental filtering of morphologically diverse ants. PeerJ 3:e1356.

Ossola A, Hahs AK, Nash MA, Livesley SJ (2016). Habitat complexity enhances comminution and decomposition processes in urban ecosystems. Ecosystems 19(5):927-941.

Pinheiro J, Bates D, DebRoy S, Sarkar D, Team RC (2015). nlme: Linear and Nonlinear Mixed Effects Models. R package version 3.1-120.

Prescott CE, Grayston SJ (2013) Tree species influence on microbial communities in litter and soil: Current knowledge and research needs. For Ecol Manage 309:19-27.

Preston-Mafham J, Boddy L, Randerson PF (2002) Analysis of microbial community functional diversity using sole-carbon-source utilisation profiles - A critique. FEMS Microbiol Ecol 42:1-4.

Ribeiro C, Madeira M, Araújo MC (2002) Decomposition and nutrient release from leaf litter of Eucalyptus globulus grown under different water and nutrient regimes. For Ecol Manage 171:31-41.

Rinkes Z, DeForest J, Grandy AS, Moorhead D, Weintraub M (2014) Interactions between leaf litter quality, particle size, and microbial community during the earliest stage of decay. Biogeochemistry 117:153-168.

Sanchez G (2013) PLS Path Modeling with R. Trowchez Editions, Berkeley, USA.

Sanchez G, Trinchera L, Russolillo G (2015) Tools for Partial Least Squares Path Modeling (PLS-PM). R Package, version 0.4.7. 
Savva Y, Szlavecz K, Pouyat RV, Groffman PM, Heisler G (2010) Effects of land use and vegetation cover on soil temperature in an urban ecosystem. Soil Sci Soc Am J 74:469-480.

Sayer EJ (2006) Using experimental manipulation to assess the roles of leaf litter in the functioning of forest ecosystems. Biol Rev 81:1-31.

Setälä H, McLean MA (2004) Decomposition rate of organic substrates in relation to the species diversity of soil saprophytic fungi. Oecologia 139:98-107.

Smith AP, Marín-Spiotta E, Balser T (2015) Successional and seasonal variations in soil and litter microbial community structure and function during tropical postagricultural forest regeneration: a multiyear study. Glob Chang Biol 21:3532-3547.

Šnajdr J, Cajthaml T, Valášková V, Merhautová V, Petránková M, Spetz P, Leppänen K, Baldrian P (2011). Transformation of Quercus petraea litter: successive changes in litter chemistry are reflected in differential enzyme activity and changes in the microbial community composition. FEMS Microbiol Ecol 75:291-303.

Strickland MS, Lauber C, Fierer N, Bradford MA (2009). Testing the functional significance of microbial community composition. Ecology 90:441-451.

Threlfall GC, Ossola A, Hahs AK, Williams NSG, Wilson L, Livesley SJ (2016). Variation in vegetation structure and composition across urban green space types. Front Ecol Evol $4: 66$.

Voriskova J, Baldrian P (2013) Fungal community on decomposing leaf litter undergoes rapid successional changes. Isme J 7:477-486.

Weber KP, Grove JA, Gehder M, Anderson WA, Legge RL (2007) Data transformations in the analysis of community-level substrate utilization data from microplates. $\mathbf{J}$ Microbiol Methods 69:461-469. 
Weber KP, Legge RL (2010). Community-level physiological profiling. In: Cummings SP Ed., Bioremediation, Methods in Molecular Biology. Humana Press. pp 263-281.

Wohl DL, Arora S, Gladstone JR (2004) Functional redundancy supports biodiversity and ecosystem function in a closed and constant environment. Ecology 85:1534-1540.

Wu J, Liu Z, Wang X, Sun Y, Zhou L, Lin Y, Fu S (2011) Effects of understory removal and tree girdling on soil microbial community composition and litter decomposition in two Eucalyptus plantations in South China. Funct Ecol 25:921-931.

Yao H, Bowman D, Shi W (2006) Soil microbial community structure and diversity in a turfgrass chronosequence: Land-use change versus turfgrass management. Appl Soil Ecol 34:209-218.

Zak JC, Willig MR, Moorhead DL, Wildman HG (1994) Functional diversity of microbial communities: A quantitative approach. Soil Biol Biochem 26:1101-1108.

Zhao D, Li F, Yang Q, Wang R, Song Y, Tao Y (2013) The influence of different types of urban land use on soil microbial biomass and functional diversity in Beijing, China. Soil Use Manage 29:230-239. 
Table 1: Effects of habitat complexity type, substrate (soil, litter) and time since land-use change upon Shannon diversity index $(\mathrm{H})$ and evenness $(\mathrm{E})$ modelled using linear mixedeffect models. High-complexity remnants (HCR) were never subjected to land-use change in the last century, as opposed to high-complexity parks (HCP) and low-complexity parks (LCP). Site was used as random-effect factor. Numbers in parentheses represent the degrees of freedom for each F-test.

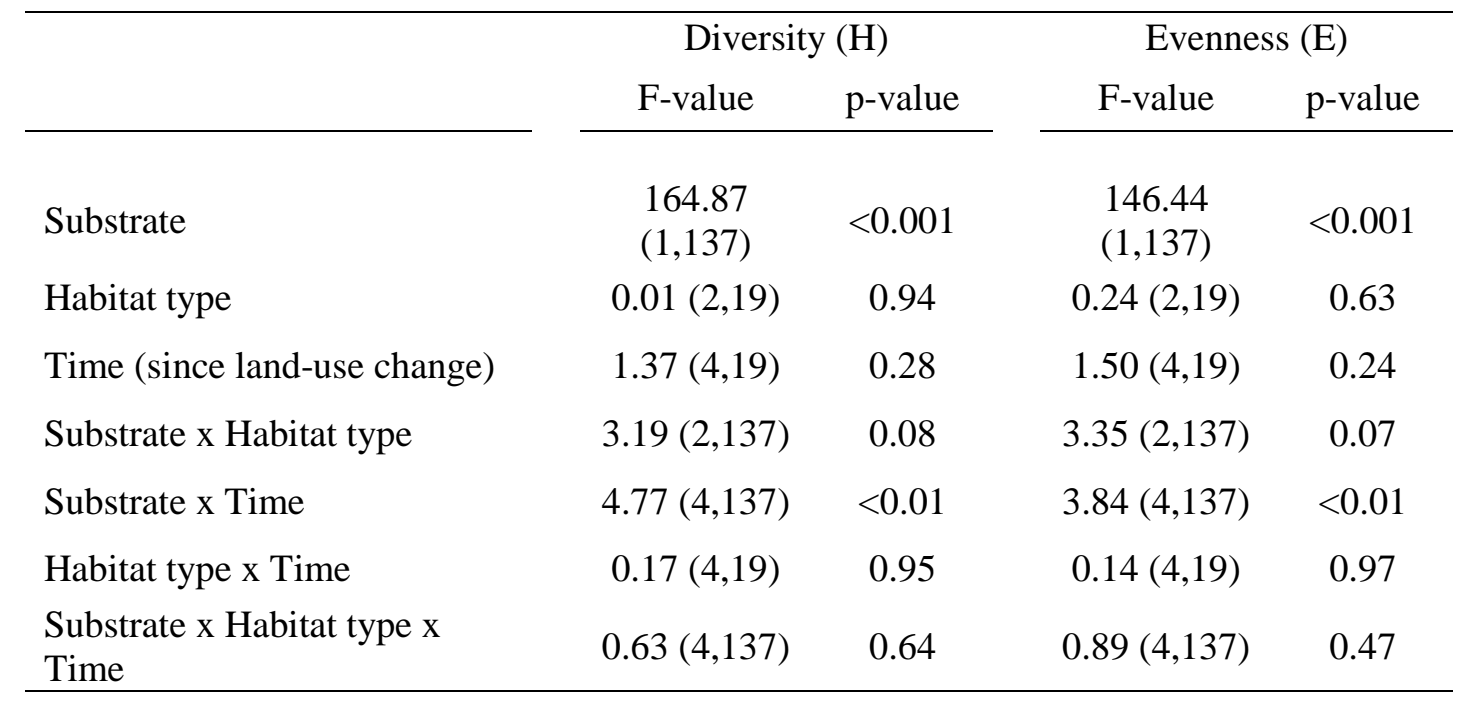


Table 2: Post PERMANOVA pairwise comparison of the functional composition of bacterial communities in the habitat complexity types (high-complexity remnant, HCR; highcomplexity park, HCP; low-complexity park, LCP) and substrates (litter, soil) based on the single $\mathrm{C}$ sources and the functional guilds (Table 3 ). The probability by permutation $\left(\mathrm{P}_{\text {perm }}\right)$, the number of unique permutations computed (perm) and the values of the pseudo-t statistic are reported.

\begin{tabular}{|c|c|c|c|c|c|c|}
\hline \multirow[b]{2}{*}{ Groups } & \multicolumn{3}{|c|}{ C sources } & \multicolumn{3}{|c|}{$\mathrm{C}$ guilds } \\
\hline & pseudo-t & $\mathrm{P}_{\text {perm }}$ & perm & pseudo-t & $\mathrm{P}_{\text {perm }}$ & perm \\
\hline HCRlitter, LCPlitter & 1.86 & $<0.001$ & 92597 & 2.43 & $<0.001$ & 95860 \\
\hline HCRlitter, HCPlitter & 1.08 & 0.28 & 92795 & 1.11 & 0.28 & 95607 \\
\hline HCRlitter, HCRsoil & 3.04 & $<0.001$ & 92929 & 2.84 & $<0.001$ & 95757 \\
\hline HCRlitter, LCPsoil & 3.36 & $<0.001$ & 93134 & 3.32 & $<0.001$ & 95850 \\
\hline HCRlitter, HCPsoil & 3.22 & $<0.001$ & 92927 & 3.41 & $<0.001$ & 95859 \\
\hline LCPlitter, HCPlitter & 1.63 & $<0.001$ & 92528 & 2.67 & $<0.001$ & 95665 \\
\hline LCPlitter, HCRsoil & 3.47 & $<0.001$ & 92759 & 2.49 & $<0.001$ & 95851 \\
\hline LCPlitter, LCPsoil & 3.41 & $<0.001$ & 92860 & 3.13 & $<0.001$ & 95726 \\
\hline LCPlitter, HCPsoil & 3.43 & $<0.001$ & 92735 & 2.94 & $<0.001$ & 95841 \\
\hline HCPlitter, HCRsoil & 3.02 & $<0.001$ & 92718 & 3.10 & $<0.001$ & 95862 \\
\hline HCPlitter, LCPsoil & 3.16 & $<0.001$ & 93096 & 3.27 & $<0.001$ & 95923 \\
\hline HCPlitter, HCPsoil & 3.09 & $<0.001$ & 92753 & 3.53 & $<0.001$ & 95877 \\
\hline HCRsoil, LCPsoil & 1.72 & $<0.001$ & 92322 & 1.56 & 0.07 & 95710 \\
\hline HCRsoil, HCPsoil & 0.99 & 0.47 & 91790 & 1.02 & 0.36 & 95930 \\
\hline LCPsoil, HCPsoil & 1.01 & 0.41 & 92019 & 1.02 & 0.36 & 95979 \\
\hline
\end{tabular}


Table 3: Loadings for the 'functional composition (C sources)' latent variable in the PLSPM model (Figure 4A). Values $>|0.40|$ are highlighted in bold. The classification of the different $\mathrm{C}$ sources in functional guilds is based on Leflaive et al. (2005).

\begin{tabular}{|c|c|c|c|}
\hline Well & Carbon source & Functional guild & Loading \\
\hline A1 & Blank (water) & - & - \\
\hline $\mathrm{A} 2$ & $\beta$-Methyl-D-Glucoside & Carbohydrate & 0.446 \\
\hline A3 & D-Galactonic Acid $\gamma$-Lactone & Carbohydrate & -0.055 \\
\hline A4 & L-Arginine & Amino acid & -0.493 \\
\hline $\mathrm{B} 1$ & Pyruvic Acid Methyl Ester & Carboxylic acid & -0.077 \\
\hline $\mathrm{B} 2$ & D-Xylose & Carbohydrate & 0.450 \\
\hline B3 & D-Galacturonic Acid & Carboxylic acid & -0.002 \\
\hline B4 & L-Asparagine & Amino acid & -0.549 \\
\hline $\mathrm{C} 1$ & Tween 40 & Polymer & -0.213 \\
\hline $\mathrm{C} 2$ & i-Erythritol & Carbohydrate & -0.146 \\
\hline $\mathrm{C} 3$ & 2-Hydroxy Benzoic Acid & Phenolic compound & 0.065 \\
\hline $\mathrm{C} 4$ & L-Phenylalanine & Amino acid & -0.016 \\
\hline $\mathrm{D} 1$ & Tween 80 & Polymer & 0.075 \\
\hline D2 & D-Mannitol & Carbohydrate & 0.405 \\
\hline D3 & 4-Hydroxy Benzoic Acid & Phenolic compound & -0.057 \\
\hline D4 & L-Serine & Amino acid & -0.626 \\
\hline E1 & $\alpha$-Cyclodextrin & Polymer & 0.157 \\
\hline $\mathrm{E} 2$ & N-Acetyl-D-Glucosamine & Carbohydrate & -0.058 \\
\hline E3 & $\gamma$-Hydroxybutyric Acid & Carboxylic acid & 0.061 \\
\hline E4 & L-Threonine & Amino acid & 0.322 \\
\hline $\mathrm{F} 1$ & Glycogen & Polymer & 0.141 \\
\hline $\mathrm{F} 2$ & D-Glucosaminic Acid & Carboxylic acid & 0.284 \\
\hline F3 & Itaconic Acid & Carboxylic acid & -0.179 \\
\hline $\mathrm{F} 4$ & Glycyl-L-Glutamic Acid & Amino acid & 0.247 \\
\hline G1 & D-Cellobiose & Carbohydrate & 0.505 \\
\hline $\mathrm{G} 2$ & Glucose-1-Phosphate & Carbohydrate & 0.418 \\
\hline G3 & $\alpha$-Ketobutyric Acid & Carboxylic acid & 0.320 \\
\hline G4 & Phenylethyl-amine & Amine & -0.447 \\
\hline $\mathrm{H} 1$ & $\alpha$-D-Lactose & Carbohydrate & 0.379 \\
\hline $\mathrm{H} 2$ & 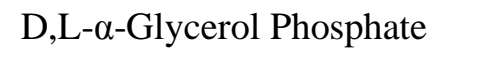 & Carbohydrate & 0.176 \\
\hline $\mathrm{H} 3$ & D-Malic Acid & Carboxylic acid & 0.281 \\
\hline $\mathrm{H} 4$ & Putrescine & Amine & -0.080 \\
\hline
\end{tabular}


Figure 1: Non-metric multidimensional scaling (NMDS) ordinations of the research plots classified in the three habitat complexity types (high-complexity remnant, HCR; highcomplexity park, HCP; low-complexity park, LCP) based on A) all the habitat complexity variables (reported in grey) and B) only the soil variables. Average values for each habitat complexity variable in relation to habitat complexity type are reported in Ossola et al. (2015b).
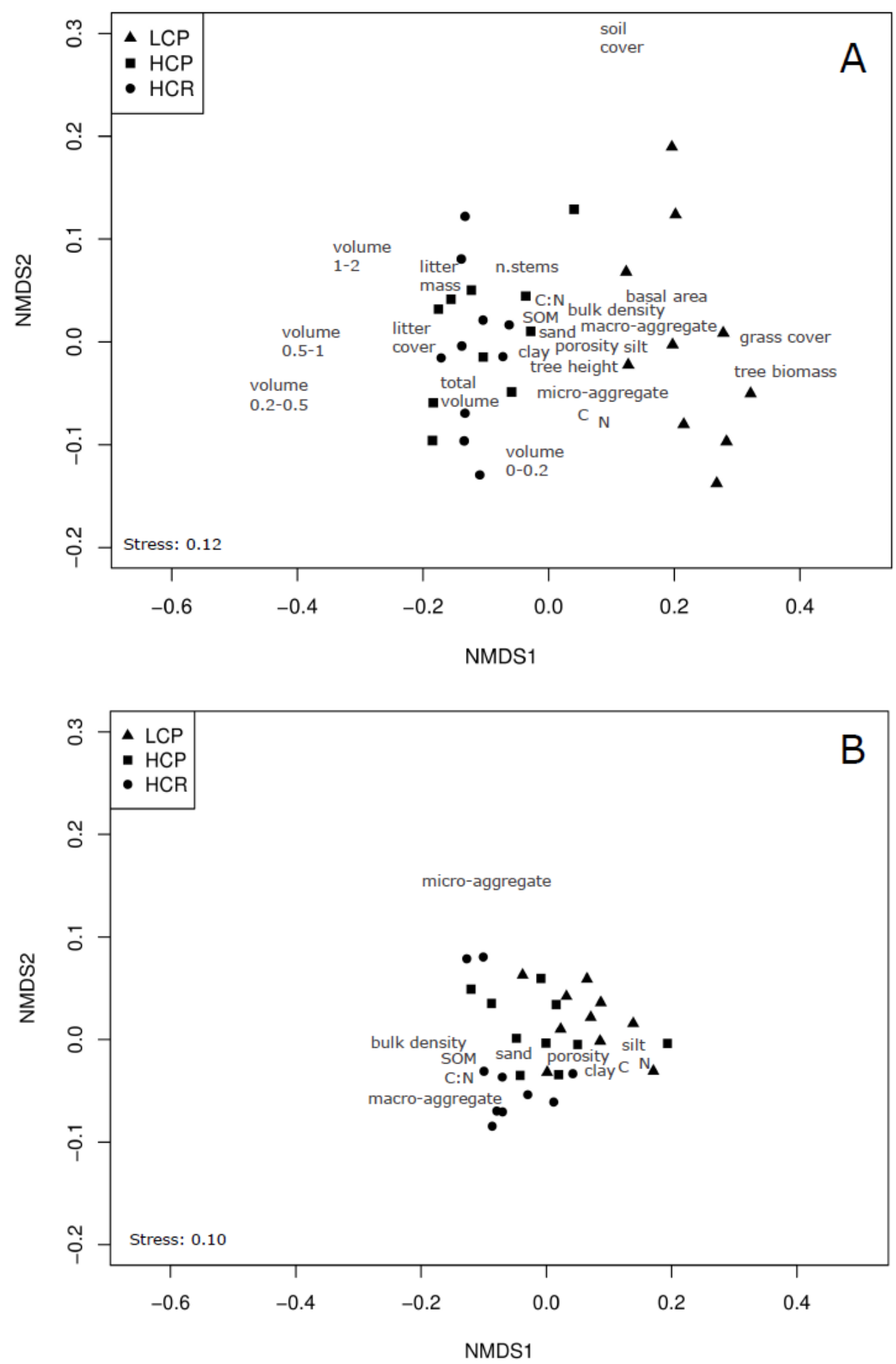
Figure 2: Metabolic functional diversity $(\mathrm{H})$ and evenness $(\mathrm{E})$ of soil and litter bacterial communities in the three habitat complexity types in relation to time since land-use change. High-complexity remnants (HCR) were never subjected to land-use change, as opposed to high-complexity parks (HCP) and low-complexity parks (LCP). Bars represent the average values, while error bars the standard error of the mean.
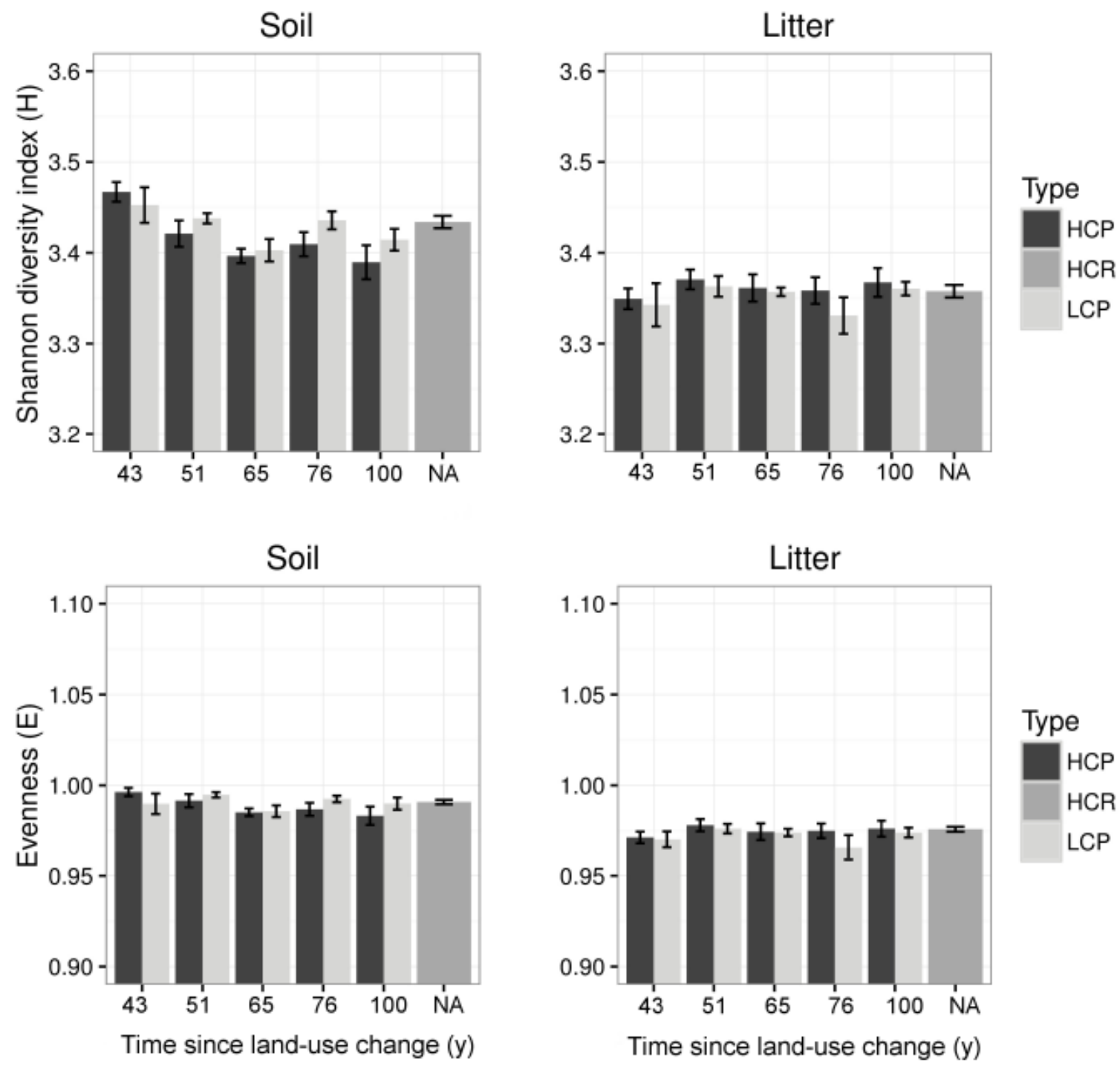
Figure 3: Functional composition of bacterial communities living on the litter (empty symbols) and in the soil (solid symbols) in the three habitat complexity types (highcomplexity remnant, HCR; high-complexity park, HCP; low-complexity park, LCP) modelled with NMDS ordinations based on A) the absorbance data of each of the 31 carbon sources at $96 \mathrm{~h}$ of incubation and B) the absorbance of the carbon sources classified in functional guilds following Leflaive et al. (2005). Bars represent the standard error of the mean. Labels of carbon substrates and functional guilds are presented in Table 3.
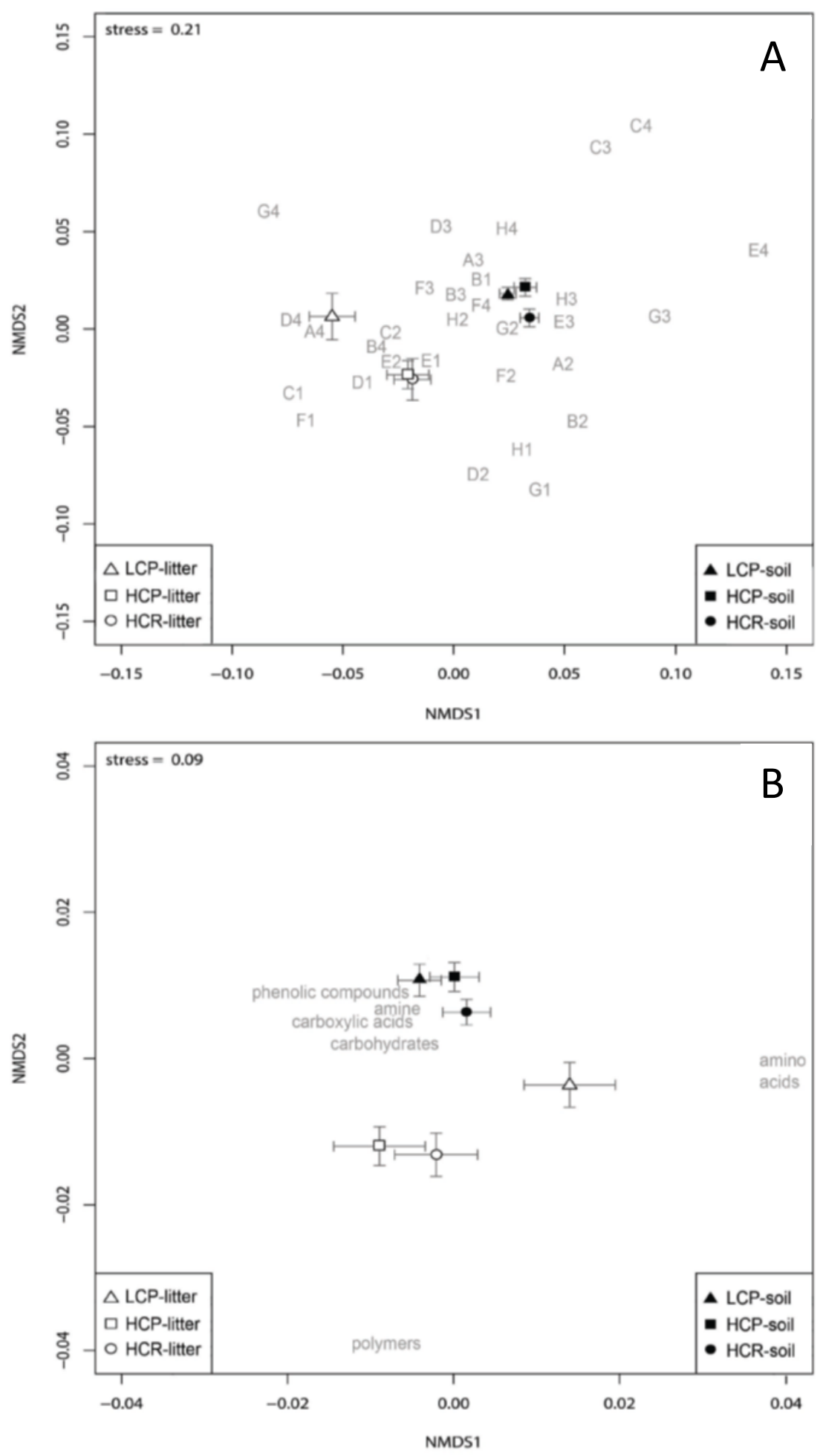
Figure 4: Path graphs (PLS-PMs) connecting 'habitat and microclimate', 'decomposition status' and A) 'functional composition (C sources)', B) 'functional composition (guilds)' and C) 'metabolic functional diversity' of litter bacterial communities. Latent variables are enclosed in ellipses and observed variables in rectangles. Numbers between observed and latent variables are correlation coefficients (loadings). Path coefficients between latent variables and $\mathrm{R}^{2}$ have been calculated through bootstrapping $(\mathrm{n}=1000)$. Significant paths are highlighted in bold $(* * * \mathrm{p}<0.001, * *<0.01, *<0.05)$. Observed variables for the 'functional composition (C sources)' latent variable (A) have been excluded from graphing for clarity and loadings are reported in Table 3.

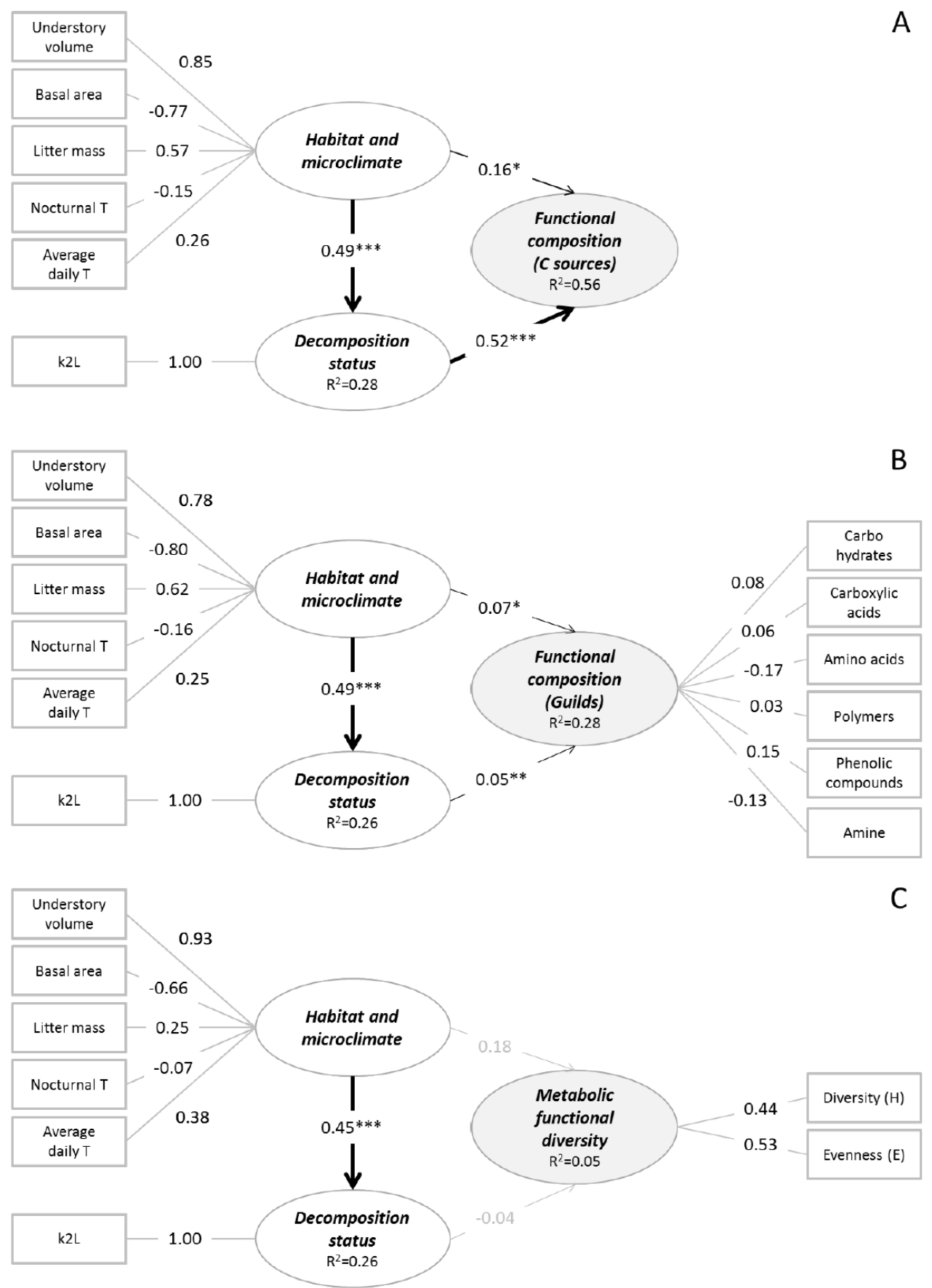




\section{University Library}

\section{- M M I N E R VA \\ A gateway to Melbourne's research publications}

Minerva Access is the Institutional Repository of The University of Melbourne

Author/s:

Ossola, A;Aponte, C;Hahs, AK;Livesley, SJ

Title:

Contrasting effects of urban habitat complexity on metabolic functional diversity and composition of litter and soil bacterial communities

Date:

2017-06-01

Citation:

Ossola, A., Aponte, C., Hahs, A. K. \& Livesley, S. J. (2017). Contrasting effects of urban habitat complexity on metabolic functional diversity and composition of litter and soil bacterial communities. URBAN ECOSYSTEMS, 20 (3), pp.595-607. https://doi.org/10.1007/ s11252-016-0617-2.

Persistent Link:

http://hdl.handle.net/11343/283188 